\title{
ANALYSIS AND SELECTION OF TECHNICAL MEANS IN ORDER TO DETECTING DEFECTS IN FABRICS
}

\author{
Sh.A. Suleymanova \\ Tashkent State Technical University, Uzbekistan \\ Email: red engineer94@mail.ru
}

\begin{abstract}
There have been carried out analysis of known works on the automation of detection of defects in fabrics in circular knitting and other weaving machines. The principles of construction, operation and methods of detecting defects based on developments and inventions have been studied. When analyzing and choosing devices and systems for detecting defects, the main attention was paid to the possibility of providing a system with a wide resolution, allowing for guaranteed detection of fabric defects. The selected detection system should be able to scan and detect defects in materials up to $3 \mathrm{~m}$ wide or more. It was determined that in order to detect defects in base of computer technology uses multiple complex algorithms. As a result of the analysis, it was concluded that about $80 \%$ of the known works are of a theoretical or recommendatory nature. The known systems are not mass-produced and have disadvantages associated with the complexity and inaccuracy of both information processing and the inaccuracy of detecting defects.
\end{abstract}

Keywords: Fabrics, Algorithm, Automation, Photodetector, Random Access Memory.

\section{Introduction}

The aim of the work is to study, analyze known means and methods for detecting, monitoring and evaluating defects on fabrics produced during production.

Based on the features and characteristics of the defects detection on fabrics surfaces, the proposed approaches (methods) were divided into six categories: statistical, spectral, structural, model approaches, comparative combination studies and computational methods. Each approach has its own basic principles and techniques, as well as advantages and disadvantages. Surprisingly, in the course of various studies, it was found that the ideal approach to detect all fabric defects does not yet exist.

During the control automating of a fabric defect, the costs and time for detecting defects are reduced, the quality of fabric production and other factors that ultimately lead to an increase in the competitiveness of manufactured products and a decrease in rejects caused by defects are increased. However, an automated inspection system requires accurate and efficient defect detection algorithms.

It has been established that one of the most promising methods and means for detecting defects is defect detection using computer technology. Here are some types of defects and the reasons leading to them. Defects may appear due to a broken cutter, ends, irregularities, holes, stitches, knots, loose thread, start mark, oil stains and marks, poor edge, double cutter, twisting.
Cracks and holes are classified as serious defects that can be caused by many reasons, such as a broken needle or a malfunctioning machine. Oil stains are mainly caused by an excessive amount of oil in the equipment. Multiple mesh are minor defects caused by multiple broken threads. A broken end appears in fabrics when the warp of the yarn is torn during weaving. Thick and thin streak defects appear when yarn deviations occur. The torn weft occurs when the filler yarn breaks during the weaving process. The wrong weft $d$ effect occurs when the weaving process does not follow the schematic pattern during the insertion of the weft. There are different categories of fabric defects and many ways to classify them, for example, typical fabric defects or classification by fabric color.

Numerous algorithms are used to detect defects based on computer technology. Most computer vision algorithms are designed for grayscale images and use different feature extraction approaches to create distinctive representations of images. In addition, grayscale image processing can extract descriptors more easily than color images, and grayscale image processing can reduce computational complexity. In work are studied [1-3] methods and technical means, development of engineers and scientists for the detection of defects. It is shown that the selected control system must provide a resolution that allows for guaranteed detection of fabric defects. Fabrics produced by textile industries using modern technologies have a width of up to $3 \mathrm{~m}$ or more, therefore, the developed 
or selected control system should ensure the control of fabrics over the entire width.

\section{Analysis of the Facilities for Solving the Problem}

For each approach, there are basic principles and techniques, as well as their advantages and disadvantages. Moreover, since the systems used are still considered very expensive, only a few automated fabric inspection systems are currently available on the market[4].

In the work [5] was analyzed the detection and registration of defects on a moving fabrics. The system operates as follows: a lighting device sends light to the fabric, which is monitored. The light reflected from the fabric, carrying information about defects, is received by the photodetector. The disadvantage of this design is the too stringent requirements for the proximity of the technical characteristics of a large number of elements of the lighting and photodetector rulers, which ultimately affects the accuracy of defect recognition.

Computers can carry out automation of the operation of recognizing fabric defects. This requires a large number of special recognition algorithms adapted to a particular type of fabric defect [6], [7]. However, at the same time, there are a large number of defects that appear during spinning, weaving and finishing. Special algorithms require the calculation of different features, which increases the recognition time. This requires the development of a complex but versatile algorithm.

There is a well-known method of informative harmonics [8], which states that there are always certain frequencies at which the filters are most sensitive to information about certain flaws. The number and frequency of adjustment of these filters must be selected from the given accuracy of recognition and evaluation of features in the form of responses of these filters to the presented image of fabric with defects [9]. The "discriminating power" of features can be assessed using the criterion [5], which is equal to the ratio of the product of data variances relative to the class standard to the squared distance between classes. However, this criterion compares only two classes of defects. In the practice of non-destructive quality control of roll materials, high-speed television systems with video conversion devices are used, made on multi-element photoelectric converters of the CCD (Charge-Coupled Device) type, or CCD - a charge-coupled device that has significant drawbacks associated with the presence of aperture distortions, a limited area frame, etc. Despite the relatively high performance of such technical vision systems (STS), the implemented technical solutions and recognition algorithms do not always allow real-time detection of defects in textile materials $[6,7,8]$. Known systems for automated quality control [9-16].

A feature of these complex is the software is capable of collecting statistical data on defects, it can check the quality of fabrics with a width of 110 to 440 centimeters at a speed of up to $120 \mathrm{~m} / \mathrm{min}$ and can detect defects up to a resolution of $0.3 \mathrm{~mm}$. Known multichannel quality control system for textile materials [17]. The block diagram of the proposed automated fabric quality control system is shown in Fig. 1. A feature of the system is the use of two microprocessors: one for the formation of software thresholds, the other for video signal processing.

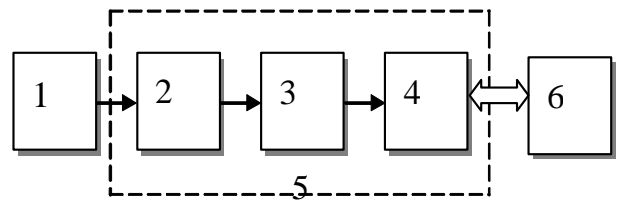

Figure 1: Generalized structure diagram of a single-channel fabric quality control system

1 - controlled object, 2 - information perception unit, 3 - image preprocessing subsystem, 4 - defect classification subsystem, 5 - quality control system, 6 - Automized controlling system local network.

The system consists of an image-sensing unit, an image preprocessing system and a defect classification system.

The main parameters of microprocessors, which are used in adaptive photo converters, are: software, instruction set, speed, random access memory (RAM) capacity and hardware [19, 20].

To determine the coordinates of the controlled object, an algorithm was used that implements the following formula:

$$
x=\frac{\sum_{\mathrm{i}} a_{\mathrm{i}} V_{i}}{\sum_{i j} V_{\mathrm{i}_{j}}}, \quad y=\frac{\sum_{j} a_{j} V_{j}}{\sum_{j} V_{\mathrm{i}_{j}}}
$$

where $a_{i}, a_{j}$ are the weight coefficients of the row and column elements, respectively;

$$
V_{i}=\sum_{j} V_{i j}
$$

$\mathrm{Vj}$ - column output signal; Vij - signal from the receiver elements.

For an accurate assessment, the duration of the algorithm execution is calculated, where $\mathrm{T}$ is the total program execution time

$$
\mathrm{T}=\sum_{j=1}^{n_{k}} p_{i} \tau_{i}+\sum_{j=1}^{m_{n n}} r_{j}
$$


where $\mathrm{p}_{\mathrm{i}}$ is a command of duration $\tau_{i} ; n_{k}$ is the number of commands; $r_{j}$ is the duration of standard routines; $m_{p p}$ - the number of standard subroutines.

Further, after carrying out some operations, the signal from the output of the converter 5 can be determine

$$
V(t)=S_{W} \cdot a \cdot \sum_{n=1} E\left(v_{x} T_{x} n\right) R\left(v_{x} T_{x} n\right)
$$

where Sv- is the sensitivity of the transducer; a- is the length of the transducer element; $\mathrm{Rx}$ - coordinate characteristic.

Line-by-line scanning takes into account the correspondence between the speeds of the inputoutput interface $v_{v v}$ and the speed of data transfer $v_{i}$ of the converter.

$$
v_{u}=f s c\left[\log _{2} \mathrm{M}+\left(\log _{2} N\right) \cdot \sum_{i=1}^{N} x_{i}\right]
$$

where $f_{s c}$ - is the line reading frequency.

The input-output information speed of the interface $v_{v v}$ can be determined from the ratio

$$
v_{b b} \geq \int_{s c}\left[\log _{2} \mathrm{M}+\left(\log _{2} N\right) \cdot \sum_{i=1}^{N} x_{i}\right]
$$

It is advantageous to filter fabric shades during dyeing in the low frequency range, and control of weaves (fabric structure) in the high frequency range.

According to [21], when extracting natural features of images that can be established by visual analysis, lightness (brightness), the texture of various areas of the images, and the shape of the contours are used

For effective recognition of fabric defects according to the technique considered in [22], information about the geometric position of the defect and its deviation from the average brightness of the fabric is needed. In this case, the matrix A (i, j) has dimensions of $\mathrm{m}$ rows by $\mathrm{n}$ columns. Each value of the matrix satisfies the relation $0 \leq \mathrm{A}(\mathrm{i}, \mathrm{j}) \leq 1$.

The most significant defects are spots on the fabrics, which are assigned a high score during quality control $[23,24]$. For this automatic control system, it is necessary to ensure a high probability of detecting defects of this type.

This type of images has a rather low signal-tonoise ratio, and in the task of image processing, additional processing is required [25].

To eliminate the influence of high-frequency signal components, first, linear two-dimensional smoothing operations are performed.

$$
\mathrm{C}(i, j)=\sum_{m=0}^{(M a-1)} \sum_{n=0}^{(N a-1)} A(m, n) * B\left(i-m_{j} j-n\right),
$$

where $0 \leq i \leq M a+M b-1$ and $0 \leq j \leq N a+N b-1$.

In this case, the image brightness thresholds T1, $\mathrm{T} 2, \mathrm{~T} 3,-\mathrm{T} 1,-\mathrm{T} 2,-\mathrm{T} 3$ are formulated as follows:

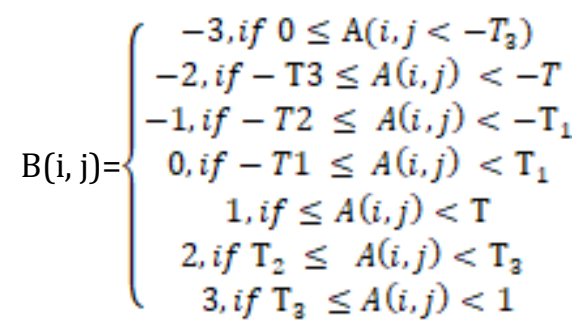

The initial values of the thresholds were selected in the training mode of the control system on fabric samples without defects, and in the future, the thresholds for detecting defects should be adjusted using the adaptive tuning system.

To improve the efficiency of the defect classification system, which is a component of the control system, it is proposed to use morphological image processing.

The use of the erosion operation in morphological processing makes it possible to exclude insignificant elements in binary images [30]

$$
(f \ominus b)(x, y)=\min \left\{f\left(x+x^{\prime}, y+y^{\prime}\right) \mid\left(x^{\prime}, y^{\prime}\right) \in D_{b},\right\}
$$

where $f(x, y)$ - is a image of fabric, $D_{b}$ - is a structure-forming element.

Smoothing of the image contour sections and filling the gaps of the image contours is performed using the morphological closure operation.

$$
f \cdot b=(f \oplus b) \ominus_{b}
$$

The resolution ability of the transducer, which is used in the microprocessor system for examining the quality of the fabric is 1575 pixels.

Determined that at a sufficiently high speed, the control system has disadvantages associated with a high level of noise, leading to a low accuracy in determining fabric defects. To eliminate these defects, a multichannel fabric quality control system was proposed [26], which also has a number of disadvantages.

As a result of performed defect detection analyzes, we found that the most effective means of detecting material defects in a circular knitting machine is a non-contact defect control system using a personal computer through intelligent software [33].

The control process, processing and detection of defects can be carried out as follows: The optical system of the video camera scans the surface of the material, then, after conversion to video signals, it 
filters the scanned area from various interferences, as a result of which the true view of the inspected area of the material is clearly established. The presence of holes or defective longitudinal lines will be clearly visible.

In order to reduce interference located along the transverse width of the material, it is necessary to smooth over the transverse width. Smoothing along the transverse width should not cover a large area of the material, otherwise the longitudinal defect line will disappear.

In the future, we divide the smoothing characteristic into horizontal lines. The number of horizontal lines should be in the range of 20-30. Next, we make a record of all the values of the points lying in the first horizontal line and a graph is built on them. The number of dots ranges from 0 to 255 (white dots). White dots are 255 and black dots are 0 .

From the plotted graph we determine (along the l-axis) the failure of the characteristic. This dip indicates that there is a longitudinal defect line in the corresponding area of the material. If the characteristic of the graph has a straight line, then this shows that the material is knitted without a defect. Therefore, when analyzing the graph, its appearance is compared with straight lines. At the same time, due to the presence of external interference in areas of the material without a defect, small jumps (oscillations) appear, and in areas where there are defects, much larger jumps appear. From the analysis of the nature of the appearance of defects on knitted materials, random interferences (defects) are revealed - discrete and continuous defects.

It has been found that to assess the numerical quality indicators of the knitted material, it is advisable to use the theory of probability, where the most important role is played by the mathematical expectation of a random variable.

According to [31,32], the main numerical characteristics for discrete random variables are:

a) distribution function;

b) a distribution series (graphically a distribution polygon).

For a continuous quantity: a) distribution function; b) distribution density.

In the theory of probability and mathematical statistics, a large number of numerical characteristics are used that have various purposes and areas of application. Here are the most frequently used ones.

From the characteristics of the position in the theory of probability, the mathematical expectation of a random variable plays the most important role.

The average value of a random variable $\mathrm{X}$ is calculated by the following formula for the mathematical expectation of a random variable:

$$
\begin{gathered}
\mathrm{M}[\mathrm{X}]=\frac{x_{1} p_{1}+x_{2} p_{2}+\cdots+x_{n} p_{n}}{p_{1}+p_{1}+\cdots+p_{1}}, \\
\text { Or, according to } \sum_{i=1}^{n} p_{i}=1, \\
\mathrm{M}[\mathrm{X}]=\sum_{i=1}^{n} x_{n} p_{n},
\end{gathered}
$$

The mathematical expectation of random values of defects X, appearing during knitting of materials, is connected in a kind of relationship with the arithmetic mean of the observed values of a random variable for a large number of experiments.

$$
\mathrm{M}^{*}[\mathrm{X}]=\sum_{i=1}^{n} x_{i} p_{i}^{*},
$$

That is, the arithmetic mean of the observed values of the random value of defects is equal to the sum of the products of all possible values of the random value of defects by the frequencies of these values.

Formula (3) for the mathematical expectation corresponds to the case of a discrete random value of defects. For a continuous quantity $\mathrm{X}$, the mathematical expectation is expressed by the integral:

$$
M[X]=\int_{-\infty}^{\infty} x f(x) d x,
$$

where $f(x)$ is the distribution density of the quantity $\mathrm{X}$.

According to the scanned data, the selected area of the material and algorithms for processing mathematical expectations corresponding to discrete and continuous values, the personal computer analyzes the selected area of the material and gives an appropriate assessment of the state of the controlled area of the material that satisfies the stated requirements.

Thus, an attempt is made in the work to describe discrete and continuous defects, which impact on during knitting by the numerical characteristics of the mathematical statistics theory of a random variable.

\section{Results and Discussions}

As a result of the study and analysis of known automation systems for control and defect detection, the following conclusions can be drawn: $80 \%$ of known works are theoretical, i.e. recommendatory nature or developed in one piece - on request.

The above rationale requires the need to develop the tendency of methods and means of control automation and detection of defects on a new basis with the use of intelligent devices, in the base of expert systems, based on a neural model. 
The application of these systems, created on the basis of modern high digital technology, with the appropriate software will lead to an increase in the accuracy of defect detection and the productivity of industrial enterprises.

\section{Conclusions}

This work was aimed at the analysis and selection of technical means for detecting defects in fabrics, using information processing methods. Various methods of detecting material defects have been studied, which include more efficient and economical ones during using process.

According to obtained results, the most effective and defining with an accuracy of $95 \%$ or more (from the point of view of detecting defects) intelligent devices in the base of expert systems based on a neural model was selected. The proposed method has enormous potential for detecting defects with a minimum amount of time spent on information processing.

\section{References}

[1] J. Zhang, J. Wang, R. Pan, J. Zhou, and W. Gao; A computer vision-based system for automatic detection of misarranged warp yarns in yarndyed fabric: part I: continuous segmentation of warp yarns, The Journal of the Textile Institute, Volume 109, Issue 5, pp. 577-584, 2018.

[2] J. Zhang, J. Wang, and R. Pan; A computer visionbased system for automatic detection of misarranged warp yarns in yarn-dyed fabric: part II: warp region segmentation, The Journal of the Textile Institute, Volume 110, Issue 9, pp. 13591367, 2019.

[3] J. Wang, J. Zhang, L. Wang, R. Pan, J. Zhou, and W. Gao; A computer vision-based system for automatic detection of misarranged color warp yarns in yarn-dyed fabric: part III: yarn layout proofing, The Journal of the Textile Institute, pp. $1-9,2020$.

[4] Abdel Salam Malek; Online fabric inspection by image processing technology. Other. University de Haute Alsace - Mulhouse, 2012. English. NNT: 2012MULH4090. Tel-00720041.

[5] Pishuxin A.M. Informatsionno-izmeritelnaya sistema klassifikatsii defektov tkani[Informationmeasuring system for classification of tissue defects]: Dis.. cand. tech. sci. - Samara, 1996.

[6] Pishuxin A.M., Korshunova T.I., Pishuxina O.A.; Patent RF na izobretenie RUS 2417366. Ustroystvo dlya obnarujeniya defektov poverxnosti dvijushegosya gibkogo materiala[Device for detecting surface defects of a moving flexible material]. published 27.04.2011, Byul. No. 12.
[7] Ajay Kumar; Computer Vision-based Fabric Defect Detection: A Survey // Industrial Electronics, IEEE Transactions on Volume 55, Issue: 1 Pp: 348 - 363. doi: 10.1109/ TIE.1930. 896476.

[8] Shevelenko V.D., Kutuzov V.I., Raimova A.T.; Filtratsiya izmeritelnix signalov formirovaniem ortogonaliziruyushix polinomov // Elektromagnitnыe volni i elektronnыe sistemi[Filtratsiya izmeritelnix signalov formirovaniem ortogonaliziruyushix polinomov // Electromagnite volni i elektronnye sistemi]. 2001, №2-3. S.35...37.

[9] Pishuxin A.M., Korshunova T.I.; Vibor znacheniy neprerivnix priznakov dlya klassifikatsii ob'ektov pri kontrole kachestva tkani [Selection of continuous feature values for classification of objects in fabric quality control] // Kontrol. Diagnostika, №5. S. Pp: 7...8, 2000.

[10] Gorelik A.L., Gurevich I.B., Skripkin V.A. Sovremennoe sostoyanie problemi raspoznavaniya: nekotorie aspekti [The current state of the problem of recognition: some aspects]. - M.: Radio i svyaz, 1985.

[11] A.N. Pisarevskiy, A.F. Chernyavskiy, G.K. Afanasev i dr.; Sistemi texnicheskogo zreniya (prinsipialnie osnovi, apparatnoe i matematicheskoe obespechenie) [Technical vision systems (fundamentals, hardware and software)], Pod obsh. red. A.N. Pisarevskogo, A.F. Chernyavskogo.-L.: $\quad$ Mashinostroenie, Leningradskoe otdelenie, 424 p, 1988.

[12] Katis G.P.; Vospriyatie i analiz opticheskoy informatsii avtomaticheskoy sistemoy[Perception and analysis of optical information by an automatic system]. -M.: Mashinostroenie, 416p, 1986.

[13] Gonsales R., Vuds R., Eddins S.; Sifrovaya obrabotka izobrajeniy v srede MATLAB [Digital image processing in MATLAB environment], M.: Texnosfera, 616p, 2006.

[14] Dockery. A.; Automated Fabric Inspection: Assessing The Current State of the Art [Electron resource] URL:http://www.techexchange.com/ thelibrary/FabricScan.html (data obrasheniya 5.05.2008).

[15] S.A.Rojkov., K.V.Timofeev , A.P. Xrapliviy, A.M.; Brajnik A.s. 1839510 SSSR, MKI D 06 H3/08 /. Ustroystvo dlya obnarujeniya defektov dvijushegosya polotna tkani $\mathrm{s}$ pechatnim risunkom[A device for detecting defects of a moving fabric with a printed pattern]. -№ 4771927/12; Zayavl. 19.12.89; d.s.p.

[16] E. Ulzhaev, Sh.N. Narzullaev, E.F. Khudoyberdiev, Sh.A. Sulaimonova; Algorithm of the process of creation of neural networks for measuring qualitative parameters of bulk materials. Proceeding of International Conference on Scientific Endeavors and opportunities, Telavi, Georgia, March, Pp: 78-81, 2021. 
[17] E.Ulzhaev, Sh.N.Narzullaev, \& O.N.Norboev, Substantiation of application of artificial neural networks for creation of humidity measuring devices. International Virtual Conference On Innovative Thoughts, Research Ideas and Inventions in Sciences, no.1(1), New York, USA, Pp: 86-91, January, 2021.

[18] Global vision to enhance your productivity [Electron resource]. - Access mode: http://www.i2s.cn/BMtelechargement.asp?chem in=/upload/secure\&fichier=Flawscan_inspection _solution_system.pdf) - Zagl. s ekrana. (Date of application: 22.07.2013).

[19] SmartView surface inspection system [Electron resource]. - Access mode: http://www.mallenom.ru/cognex_smartview.ph $\mathrm{p}$ - Zagl. s ekrana. (Date of application: 22.07.2013).

[20] NIS 200 [Electron resource]. - Access mode: http://www.lenzinginstruments.com/file_downl oad/95/NIS+200.pdf - Zagl. s ekrana. (Date of application: 22.07.2013)

[21] Bilenko M.S., Serov A.V., Rojkov S.A., Buglov O.A.; Mnogokanalnaya sistema kontrolya kachestva tekstilnix materialov [Multichannel quality control system for textile materials] Informatsionno-upravlyayushie kompleksi i sistemi [Information and control complexes and systems] AAEKS,2008, №2.

Contact Image Sensors MITSUBISHI ELECTRIC [Elektronniy resurs] URL: http://global.mitsubishielectric.com/bu/contact_ image/ove_structure.html (date of application 5.09.2008).

[22] A.N. Pisarevskiy, A.F. Chernyavskiy, G.K. Afanasev et al; Sistemi texnicheskogo zreniya (prinsipialnie osnovi, apparatnoe i matematicheskoe obespechenie) [Technical vision systems (fundamentals, hardware and software)]/ Edited by A.N. Pisarevskogo, A.F. Chernyavskiy. -L.: Mashinostroenie, Leningr. otdnie, 424 s, 1988.

[23] Mursalin T., Eishita F., Islam A.; Fabric defect inspection system using neural network and microcontroller. Journal of Theoretical and Applied Information Technology, Pp. 560-570, 2008.

[24] Rojkov S.O., Fedotova O.M.; Algoritm rozpiznavannya defektiv tkanin dlya avtomatichnoï sistemi kontrolyu yakosti[Algorithm for detecting defects in fabrics for automatic systems and quality control], Avtomatika. Avtomatizatsiya. Elektrotexnicheskie kompleksi i sistemi, Volume 1, Issue 17, Pp: 47-59, 2006.
[25] Rojkov S.O., Ternova T.I., Edinovich M.B.; Problemi avtomatizovanogo rozbrakuvannya tkanin[Problems of automated processing of fabrics], Problemi legkoy i tekstilnoy promishlennosti Ukraini, Volume 2, Issue 9, Pp: 208-215, 2004.

[26] Rojkov S.O., Ternova T.I., Edinovich M.B.; Problemi avtomatizovanogo rozbrakuvannya tkanin [Problems of automated processing of fabrics], Problemi legkoy i tekstilnoy promishlennosti Ukraini, Volume 2, Issue 9, Pp: 220-224, 2004.

[27] Gonsales R., Vuds R., Eddins S. sifrovaya obrabotka izobrajeniy $\mathrm{v}$ srede MATLAB [Digital image processing in MATLAB environment], Texnosfera, 616p, 2006.

[28] Bilenko M.S., Rojkov S.A.; Ispolzovanie CISdatchikov $\mathrm{v}$ sistemax razbrakovki tkaney [The use of KYS sensors in tissue grading systems], XV Mijnarodna konferensiya $\mathrm{z}$ avtomatichnogo upravlinnya (Avtomatika 2008). Tezi dopovidey p'yatnadsyatoï mijnarodnoï naukovo-texnichnoï konferensi, Odesa, ONMA, Pp: 57-60, 2008.

[29] IQ-TEX 4 [Electron resource]. - Access mode: http://www.evs.co.il/index.php?option=com_con tent\&view=article\&id=41\&Itemid=79 - Zagl. s ekrana. (Date of application: 23.07.2013).

[30] IN-LINE NONWOVENS INSPECTION [Electron resource]. Access mode: http://www.isravision.com/likecms.php?nav=20 $1 \&$ siteid $=\&$ entryid $=$ - Zagl. s ekrana. (Date of application: 23.07.2013).

[31] Ye. S. Ventsel; Teoriya veroyatnostey [Probability theory], Publisher: URSS, 1969.

[32] B. V. Gnedenko; Kurs teorii veroyatnostey [Probability theory course], Publisher: NAUKA, 2005.

[33] Uljaev E., Narzullayev S., Utkir U., Shoira, S.; Increasing the Accuracy of Calibration Device for Measuring the Moisture of Bulk Materials, Lecture Notes in Networks and Systemsthis, 305, Pp: 204-213, 2022.

[34] Uljayev, E., Ubaydullaev, U.M., Narzullayev, S.N., Norboyev, O.N.; Application of expert systems for measuring the humidity of bulk materials, International Journal of Mechatronics and Applied Mechanicsthis, Volume 1, Issue 9, Pp: 131-137, 2021.

[35] Uljayev, E., Ubaydullayev, U.M., Tadjitdinov, G.T., Narzullayev, S.N.; Development of Criteria for Synthesis of the Optimal Structure of Monitoring and Control Systems Advances in Intelligent Systems and Computingthis, 1323 AISC, Pp: 559563,2021 